\title{
Macromolecular Syntheses during the Cell Cycles of Yeast and Hyphal Phases of Candida albicans
}

\author{
By W. H. WAIN,* MARGARET F. PRICE, ANNE R. BRAYTON AND \\ R. A. CAWSON \\ Department of Oral Medicine and Pathology, Guy's Hospital, London SE1 $9 R T$
}

(Received 2 December 1975 ; revised 25 May 1976)

\section{SUMMARY}

Synchronous cultures of yeast and hyphal phases of Candida albicans showed exponential increases in RNA content and stepwise exponential increases in DNA content. The periods of DNA synthesis in the two phases coincided with one another and with the budding peaks of the yeast phase. Hyphae grown in synchronous cultures also showed an exponential increase in length. The hyphal phase was therefore normal.

Hyphal nuclear division occurred after hyphal DNA synthesis. Germination was a unique event for a hypha and unlike yeast bud formation, preceded the first period of DNA synthesis.

The exponential increase in RNA and DNA in asynchronous cultures of hyphae in serum paralleled the exponential increase in the numbers of cells in asynchronous cultures of yeasts in defined media. Thus there are no factors in serum which inhibit the normal exponential growth of $C$. albicans.

\section{INTRODUCTION}

Synchronous cultures have been used to investigate parameters of the cell cycle on the assumption that the cultures are normal, i.e. that the cells are identical to those in a random asynchronous culture growing exponentially in a constant environment (Mitchison, 1971). Synchronous cultures have also been used to provide reproducible inocula for growth studies with Candida albicans (Davies \& Denning, 1972) and for drug assays (Davies \& Savage, 1974).

Davies \& Denning (1972) reported a linear (arithmetic) increase in hyphal length per unit time for synchronous cultures of hyphae of $C$. albicans and similar results have been obtained for asynchronous hyphal cultures (Wain, Price \& Cawson, 1975). Davies \& Savage (1974) found that the numbers of nuclei in hyphae grown in synchronous cultures also increased arithmetically in contrast to the geometric increase in the numbers of cells (stepwise exponential increase) and presumably also in the numbers of nuclei in synchronous cultures of the yeast phase. This difference suggested that the hyphae in synchronous culture in the presence of serum were not normal according to the criteria of Mitchison (1971) and were perhaps showing unbalanced growth.

It is difficult to compare the growth of yeast and hyphal forms of C. albicans (Wain et al., I975) since total counts, viable counts and assay of extinction $(E)$ are not appropriate for estimating hyphal growth (Elin \& Wolff, 1973; Hendry, 1972). Estimates of RNA, DNA and numbers of nuclei should provide a valid basis for comparing their growth, although Dastidar (1965) has reported a difference in RNA/dry weight between the two forms.

* Present address: Homograft Department, National Heart Hospital, London WIM 8BA. 
Infections involving $C$. albicans are associated with the production of hyphae (Winner \& Hurley, 1964; Wain, Price \& Cawson, 1974), and this provides a further reason for investigating macromolecular synthesis in cultures of hyphae. The RNA and DNA contents of C. albicans during growth of synchronous yeast and hyphal forms have therefore been measured to compare the timing of synthesis in the two forms.

\section{METHODS}

Candida albicans (type culture no. 3153, Mycology Reference Collection, London School of Hygiene and Tropical Medicine) was maintained on Sabouraud's malt agar and periodically passaged on chick chorio-allantoic membranes (Partridge, Athar \& Winner, 197I). Incubation was at $37^{\circ} \mathrm{C}$ unless stated otherwise.

Synchronous yeast cultures. Synchronous cultures were prepared by the sucrose gradient technique of Mitchison \& Vincent (1965) from blastospores growing exponentially in a medium containing $5 \%(\mathrm{w} / \mathrm{v})$ glucose in Difco Yeast Nitrogen Base ( $5 \%$ glucose YNB). Samples $(2.5 \mathrm{ml})$ were siphoned from the gradient through a float which descended the gradient with the falling meniscus. A cell count was made in a haemocytometer on a dilution of each sample. A sample that contained young cells with no visible buds was suspended in prewarmed $\left(37^{\circ} \mathrm{C}\right) 5 \%$ glucose YNB medium to give $\mathrm{I} \times 10^{6}$ to $3 \times 10^{6}$ cells ml ${ }^{-1}$. To obtain $200 \mathrm{ml}$ synchronous culture at $2 \times 10^{6}$ cells ml-1 it was sometimes necessary to use equivalent samples from two gradients, i.e. samples from the same level on the gradients showing the same size distribution of non-budding blastospores. Cultures were incubated with shaking in a water bath for up to $6 \mathrm{~h}$. Samples were removed at 10 min intervals for counting in a haemocytometer, using the counting notation of Williamson \& Scopes (1962). For RNA and DNA estimations, samples ( $10 \mathrm{ml}$ ) were removed at 5 or $10 \mathrm{~min}$ intervals to $10 \mathrm{ml}$ glass centrifuge tubes, which were capped, frozen by immersion in an ethanol bath in a deep freeze at $-20{ }^{\circ} \mathrm{C}$ and stored at $-20{ }^{\circ} \mathrm{C}$.

Synchronous hyphal cultures. These were prepared in an identical manner to the synchronous yeast cultures except that the young blastospores from the sucrose gradient were resuspended in prewarmed $\left(37^{\circ} \mathrm{C}\right)$, prefiltered ( $0.45 \mu \mathrm{m}$ pore size; Millipore) human serum. The suspension of young blastospores in serum was thoroughly mixed and portions $(2 \times 5 \mathrm{ml})$ were distributed randomly into each of nineteen $25 \mathrm{ml}$ conical flasks. Cultures were incubated for up to $6 \mathrm{~h}$ with shaking in a water bath. This procedure was necessary to avoid sampling problems after the long hyphae started to clump. A control culture of synchronous blastospores in $5 \%$ glucose YNB medium was set up with each synchronous hyphal culture. This was sampled at to min intervals to find the time when the budding peaks occurred and the degree of synchrony. Peak times were taken as the mid-peak width at half peak height.

For RNA and DNA estimations, samples ( $10 \mathrm{ml}$ ) were removed at 5 or 10 min intervals to Io $\mathrm{ml}$ glass centrifuge tubes. Because the serum proteins interfered with RNA estimations, the hyphal samples were washed twice in $\mathrm{I} \%(\mathrm{w} / \mathrm{v}) \mathrm{NaCl}$ at $0^{\circ} \mathrm{C}$, and centrifuged between washes at $3600 \mathrm{~g}$ (Mistral $6 \mathrm{~L}, \mathrm{MSE}$ ) at $0^{\circ} \mathrm{C}$ for $7 \mathrm{~min}$. After removing the second supernatant the centrifuge tube was capped and the hyphal pellet was frozen in an ethanol bath in a deep freeze at $-20^{\circ} \mathrm{C}$ and stored at $-20^{\circ} \mathrm{C}$.

For measurements of germination frequency and hyphal length, samples were taken at Io min intervals and photographed in a haemocytometer. For nuclear counts, samples $(50 \mu \mathrm{l})$ were taken at $10 \mathrm{~min}$ intervals, added to $2 \mathrm{ml} \mathrm{I} \% \mathrm{NaCl}$ at $0^{\circ} \mathrm{C}$ and centrifuged at rooo $\mathrm{g}$ for $7 \mathrm{~min}$. The supernatant was discarded and the pellet was washed with $\mathrm{I} \% \mathrm{NaCl}$ at $0^{\circ} \mathrm{C}$ to remove excess serum proteins. After centrifuging for a further $7 \mathrm{~min}$, the final 
pellet was fixed in absolute methanol, which was found to be superior to both Carnoy's fixative and ether/ethanol mixtures.

$R N A$ and DNA estimations. Frozen samples were thawed at $0^{\circ} \mathrm{C}$ and the blastospores were centrifuged at $3600 \mathrm{~g}$ at $0^{\circ} \mathrm{C}$ for $15 \mathrm{~min}$. The supernatant was removed and the pellets were resuspended in $6 \mathrm{ml} 0.5 \mathrm{M}$-perchloric acid (PCA) for $30 \mathrm{~min}$ at $0^{\circ} \mathrm{C}$. Pellets were extracted,with $0.5 \mathrm{M}-\mathrm{PCA}$ at $70^{\circ} \mathrm{C}$ following the procedure of Wain \& Staatz (1973), and RNA and DNA were assayed using $0.26 \mathrm{ml}$ of the extracts. RNA was estimated from extinction measurements on dilutions of $40 \mu 1$ portions of the extracts assuming $E_{1.0 \mathrm{~cm}, 264 \mathrm{~nm}}^{0.1 \%}=25$ (Wain \& Staatz, 1973). The diphenylamine reagent (200 $\mu \mathrm{l}$; Bostock, 1970) was added to portions $(200 \mu \mathrm{l})$ of the $0.5 \mathrm{M}$-PCA extracts, and the amount of DNA was estimated from the difference in extinction at $595 \mathrm{~nm}$ and $720 \mathrm{~nm}$ using deoxyadenosine in $0.5 \mathrm{M}-\mathrm{PCA}$ as a standard. RNA and DNA contents are expressed as $\mathrm{g}$ nucleic acid per ml culture.

Hyphal length measurements. Direct microscopy (Davies \& Denning, 1972) and caliper measurements from photographs (Wain et al., 1975) do not make any allowance for bending and branching hyphae. Thus we estimated hyphal lengths from photographic enlargements of hyphae in a haemocytometer by moulding cored solder wire (I.219 $\mathrm{mm}$ diam.; $18 \mathrm{swg})$ to the shape of each hypha including the branches, weighing the wire, and calibrating weights to the internal standard length of the haemocytometer graticule. Ten replicate measurements of a single hypha after $4 \mathrm{~h}$ growth gave a mean length of $72.9 \mu \mathrm{m}$ and a standard deviation of $2 \cdot 6 \mu \mathrm{m}$.

Nuclear staining. Hyphal pellets in methanol were air-dried on glass slides and Giemsastained after I M-HCl hydrolysis (Mitchison, 1970). Nuclear counts were made on Ioo hyphae per slide and the mean count per hypha was calculated. It was not possible to stain nuclei in blastospores and it is assumed that there is only one nucleus per blastospore.

\section{RESULTS}

Results for a typical synchronous culture of yeast phase C. albicans are shown in Fig. I. The continuous exponential increase in RNA contrasts sharply with the stepwise exponential increase in DNA and in the number of cells. The midpoint of the rise in DNA was approximately coincident with both the budding peak and the midpoint of the rise in the number of cells. The mean value of seven estimates, from five different experiments, of the time of DNA synthesis was $0.94 \pm 0.03$ of the cell cycle, i.e. immediately before cell division. The control synchronous yeast cultures incubated with each synchronous hyphal culture were used to provide the cell-cycle timings for the inocula of the hyphal cultures. The mean value of five estimates, from four different experiments, of the time of hyphal DNA synthesis was $1 \cdot 03 \pm$ 0.07 of the cell cycle, i.e. immediately after yeast cell division. Individual values for periods of DNA synthesis in synchronous yeast $\left(S_{y}\right)$ and hyphal $\left(S_{h}\right)$ cultures and hyphal phase nuclear division times (ND) are shown in Fig. 2, superimposed on linear cell-cycle maps derived from yeast division times (Mitchison, I97I; Poole, Lloyd \& Kemp, 1973).

In Fig. 3, the results of four experiments on synchronous cultures of hyphae are combined by standardizing the sampling times to the budding peaks in the control yeast cultures $\left(D_{1}\right.$, $D_{2}$ and $D_{3}$ ). Estimates of DNA and RNA contents have been adjusted to an arbitrary standard from the third plateau of DNA between $D_{2}$ and $D_{3}$. This value is taken as $8 \times 10^{-2}$ $\mu \mathrm{g} \mathrm{ml}^{-1}$ for DNA and $\mathrm{i} 6 \mu \mathrm{g} \mathrm{ml}^{-1}$ for RNA. Germination to form hyphae was complete before the first period of DNA synthesis (Fig. 3), in contrast to the coincidence of yeast budding with DNA synthesis (Fig. I). The coincidence of $D_{1}, D_{2}$ and $D_{3}$ with the midpoint of the DNA increase in hyphal cultures shows that DNA synthesis in hyphae is coincident 


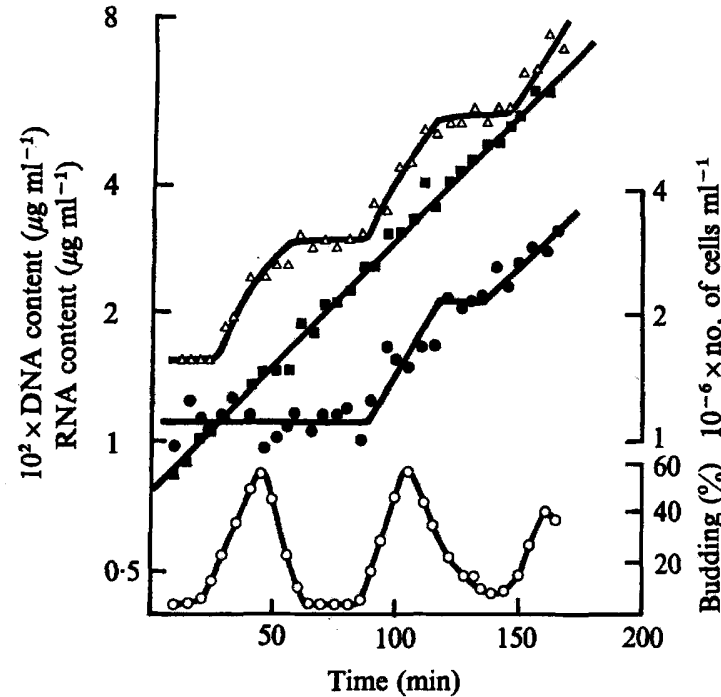

Fig. I
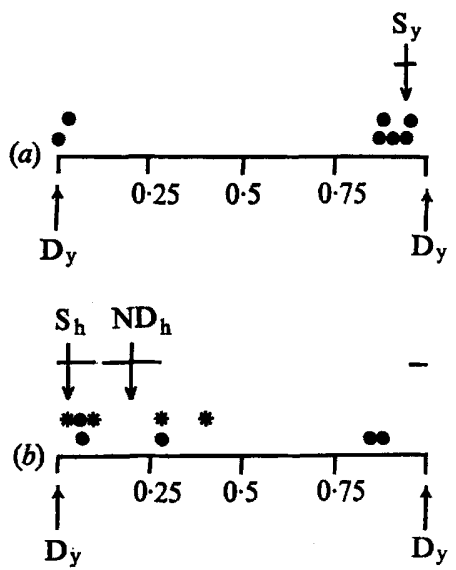

Fig. 2

Fig. I. Synchronous culture of yeast phase Candida albicans. A synchronous culture (200 $\mathrm{ml})$ in $5 \%$ glucose YNB was prepared by sedimentation selection from an asynchronous exponential culture. Samples were taken at intervals to determine cell counts and budding, and for DNA and RNA estimations. The budding peaks are the midpoints of the peaks of the lowest curve, which shows the percentage of cells associated with a bud of less than one-fifth of the parent size. $\mathbf{n}, \mathrm{RNA}$; $\triangle$, DNA;, number of cells; $O$, budding ( $\%$ ).

Fig. 2. Cell-cycle maps indicating timings in synchronous cultures of yeast and hyphal phases of Candida albicans. (a) Yeast phase division $\left(\mathrm{D}_{\mathrm{y}}\right)$ map showing yeast phase DNA synthesis $\left(\mathrm{S}_{\mathrm{y}}\right)$. (b) Yeast phase division $\left(D_{y}\right)$ map showing hyphal phase DNA synthesis $\left(S_{h}\right)$ and hyphal phase nuclear division $\left(\mathrm{ND}_{\mathrm{b}}\right)$. $\mathrm{O}$, Time of the midpoint in the rise of DNA synthesis; *, time of the midpoint in the rise in the number of nuclei. Arrows with cross bars show mean values with standard errors. The staining technique did not permit the detection of yeast phase nuclei. It is assumed that there is only one nucleus per blastospore.

with budding peaks and also with DNA synthesis in yeast cultures. The continuous increase in hyphal length paralleled the increase in RNA.

The change in mean nuclear counts (Fig. 3) did not suggest that there was a stepwise exponential (geometric) increase in the number of nuclei per hypha, i.e. from I to 2 to 4 to 8 , following the three periods of DNA synthesis. Equally the stepwise increase did not appear to be arithmetic, i.e. from I to 2 to 3 to 4 . The experimental values of I (assumed for the first blastospore) to 2 to 3.7 to 5.6 might be underestimates of the number of nuclei present: it is unlikely that they are overestimates as the method of counting takes no account of apparently anucleate hyphae, i.e. unstained hyphae. We have therefore interpreted the results as supporting the concept of an exponential increase in the number of hyphal nuclei, similar to the increase in hyphal DNA, yeast phase DNA and numbers of yeast cells.

An asynchronous hyphal culture (Fig. 4) showed parallel, continuous and exponential increases in both RNA and DNA with a mean doubling time of $6 \mathrm{I} \mathrm{min}$. No measurements were made on cultures incubated for less than $200 \mathrm{~min}$ because the information was required for up to $7 \mathrm{~h}$ incubation and we only had a limited number of samples. 


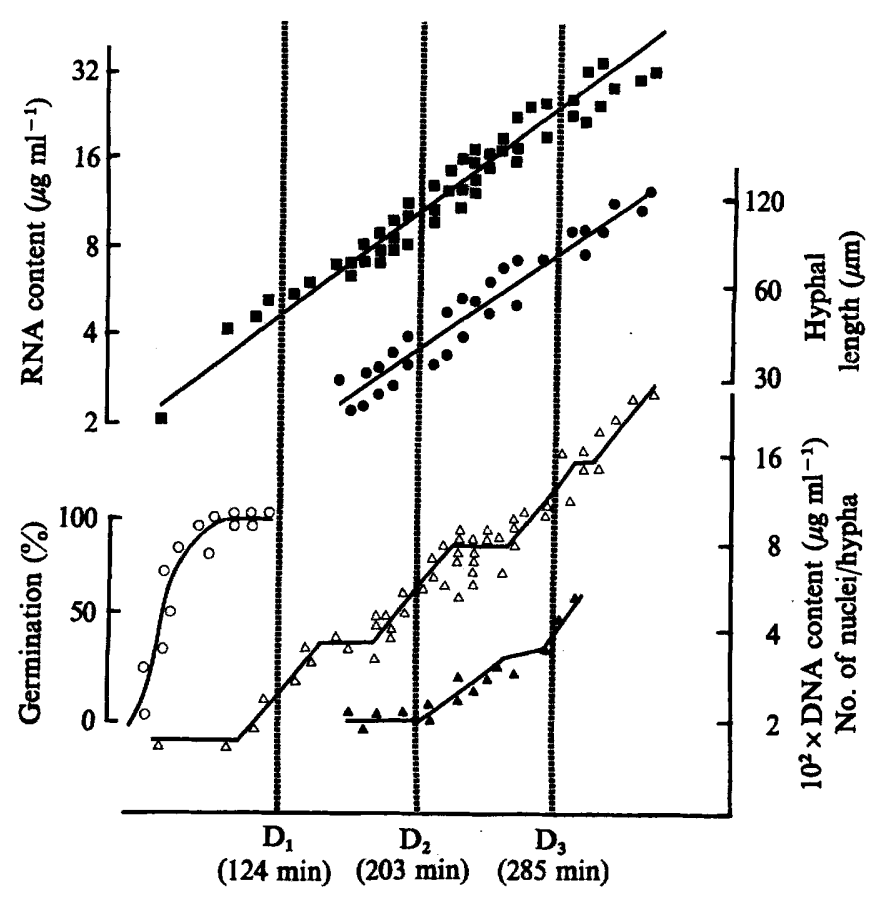

Fig. 3. Synchronous cultures of hyphal phase Candida albicans. Synchronous cultures (200 $\mathrm{ml})$ in filtered human serum were prepared by sedimentation selection from asynchronous exponential cultures in $5 \%$ glucose YNB. Each culture was divided into $10 \mathrm{ml}$ portions at the start of each experiment. Samples were taken at intervals to determine the extent of germination; the hyphal length; the mean nuclear count; and for RNA and DNA estimations.

A synchronous yeast culture from the same inoculum was prepared in parallel with each synchronous hyphal culture. This yeast culture was used to provide the times of cell division, $D_{1}, D_{2}$ and $D_{3}$. The mean time from the start of the experiment is also shown, e.g. $D_{1}$ (124 min). The times at which the samples were taken from each hyphal culture were expressed as fractions of the yeast cell division cycle in the parallel culture. The values for DNA and RNA in each culture were calculated in arbitrary units related to the mean value of DNA on the plateau between $\mathrm{D}_{2}$ and $\mathrm{D}_{3}$ for that culture. This was given a value of $8 \times 10^{-2} \mu \mathrm{g} \mathrm{ml}^{-1}$ for DNA and the equivalent RNA sample was assigned a value of $16 \mu \mathrm{g} \mathrm{ml}^{-1}$. The DNA and RNA were extracted from $10 \mathrm{ml}$ samples which contained $2 \times 10^{7}$ to $3 \times 10^{7}$ cells at the start of the experiment.

The combined results of four experiments are presented. I, RNA; $\triangle$, DNA; 9 , hyphal length ; $O$, germination; $\boldsymbol{\Delta}$, number of nuclei/hypha.

\section{DISCUSSION}

The results in Figs I and 3 show that RNA and DNA increased exponentially in synchronous cultures of both the yeast and hyphal phases of $C$. albicans. Figures 2 and 3 show that the hyphal DNA was synthesized at the same time as yeast DNA in parallel synchronous yeast cultures. This coincidence of the periods of yeast and hyphal DNA synthesis is an expression of identical growth rates. Identical growth rates may also be seen by comparing the doubling time (6I min) for DNA and RNA in synchronous hyphal cultures (Fig. 4) with the mean doubling time $(63 \pm 3 \mathrm{~min}$ ) of yeast cultures growing exponentially (Wain et al., 1975). The identical growth rates and the exponential increase in hyphal DNA both indicate that the hyphal phase of C. albicans was normal, according to the criteria of Mitchison (I971).

It was not easy to estimate the number of nuclei in hyphal preparations. If the values in Fig. 3 are assumed to be underestimates, then the numbers of nuclei per hypha increased in a geometric progression giving an approximately exponential increase although the data do 


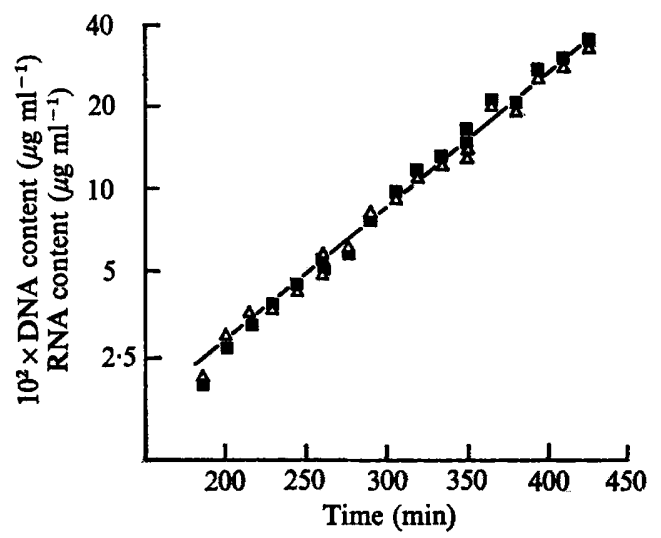

Fig. 4. Asynchronous culture of hyphal phase of Candida albicans. An asynchronous culture $(200 \mathrm{ml})$ in filtered human serum was prepared by re-inoculation of an $18 \mathrm{~h}$ stationary phase culture in $5 \%$ glucose YNB. The culture was divided into $10 \mathrm{ml}$ portions at the start of the experiment. Samples were taken at intervals for RNA and DNA estimations. $n$, RNA; $\triangle, D N A$.

not allow a definite conclusion to be drawn. An exponential increase in mean nuclear number per hypha has been recorded in Aspergillus nidulans spore germination after the initial synchronous division (Bainbridge, 1971).

Simple measurements of hyphal length have suggested that $C$. albicans hyphae increase in length in an arithmetic manner (Davies \& Denning, 1972; Wain et al., 1975) whereas the present, more precise, method of measuring the increase in hyphal length indicated an exponential increase (Fig. 3). This exponential increase with time paralleled the increase in hyphal RNA and is compatible with the exponential increases in hyphal length found in other fungi (Trinci, 1974).

Thus the four parameters of growth (Fig. 3) all show an exponential increase indicating that the hyphal phase of $C$. albicans is a normal one.

Hyphal germination occurred before the first period of DNA synthesis (Fig. 3) whereas the budding peak coincided with yeast and hyphal DNA synthesis. This implies that the expression of hyphal morphology does not require the influence of any mediating factors in serum on DNA synthesis de novo. The synchronous inocula were selected from a population of budding $C$. albicans and the first hyphal outgrowths appeared before the first buds were seen in the control synchronous yeast culture. This development of hyphae before any DNA synthesis and before the equivalent bud formation supports the hypothesis of Evans, Odds \& Holland (1975) that dimorphism is part of a predetermined fungal life-cycle.

In addition to its role as an inducer of hyphal morphology, serum has also been described as a growth inhibitor (Hendry, 1972). However, the identical exponential growth rates of the yeast and hyphal phases of $C$. albicans show that serum has no inhibitory effect on the growth rate of the hyphal form. There is a limit to the total amount of fungal material synthesized during growth in serum (Hendry, 1972) but this is an expression of the ability of serum to maintain growth rather than an inhibition of growth. Serum supports a lower stationary phase or yield but the exponential growth rate in serum is the same as that of the yeast phase in other media. There was therefore no evidence to support the concept that factors in serum inhibit the growth rate of $C$. albicans in the hyphal form.

We are grateful to the Medical Research Council for their financial support, grant no. 972/619B. 


\section{REFERENCES}

BAINBRIDGE, B. W. (I971). Macromolecular composition and nuclear division during spore germination in Aspergillus nidulans. Journal of General Microbiology 66, 319-325.

Bostock, C. J. (1970). DNA synthesis in the fission yeast Schizosaccharomyces pombe. Experimental Cell Research 60, 16-26.

Dastidar, S. G. (1965). Studies on nucleic acids and protein contents of Candida albicans and their relationship to dimorphism. Indian Journal of Experimental Biology 4, 5I-52.

Davies, R. R. \& Denning, T. J. V. (1972). Growth and form in Candida albicans. Sabouraudia 10, I80-188.

DAVIES, R. R. \& SAVAGE, M. A. (1974). Observations on 5-fluorocytosine and Candida albicans. Sabouraudia 12, 302-308.

Elin, R. J. \& WolfF, S. M. (1973). Effect of pH and iron concentration on growth of Candida albicans in human serum. Journal of Infectious Diseases 127, 705-708.

Evans, E. G. V., Odds, F. C. \& Holland, K. T. (1975). Resistance of the Candida albicans filamentous cycle to environmental change. Sabouraudia 13, 23I-238.

HENDRY, A. T. (1972). Inhibition of catalase activity of Candida albicans by serum. Sabouraudia 10, 193-204.

Mrtchison, J. M. (1970). Methods in Cell Physiology, vol. 4, p. 131. Edited by D. M. Prescott. New York: Academic Press.

Mrtchison, J. M. (1971). The Biology of the Cell Cycle. Cambridge: Cambridge University Press.

Mrtchison, J. M. \& Vincent, W. S. (1965). Preparation of synchronous cell cultures by sedimentation. Nature, London 205, 987-989.

Partridge, B. M., ATHAR, M. A. \& WinNeR, H. I. (1971). Chick embryo inoculation as a pathogenicity test for Candida species. Journal of Clinical Pathology 24, 645-648.

POOLE, R. K., LLOYD, D. \& KEMP, R. B. (1973). Respiratory oscillations and heat evolution in synchronously dividing cultures of the fission yeast Schizosaccharomyces pombe $972 \mathrm{~h}^{-}$. Journal of General Microbiology 77, 209-220.

TRINCI, A. P. J. (1974). A study of the kinetics of hyphal extension and branch initiation of fungal mycelia. Journal of General Microbiology 81, 225-236.

WaIN, W. H. \& STAATZ, W. D. (I973). Rates of synthesis of ribosomal protein and total ribonucleic acid through the cell cycle of the fission yeast Schizosaccharomyces pombe. Experimental Cell Research 8r, 264-278.

Wain, W. H., Price, M. F. \& Cawson, R. A. (1974). The fate of Candida albicans inoculated on to the chick chorio-allantoic membrane. Journal of Dental Research 53, 1066.

Wain, W. H., Price, M. F. \& CAwson, R. A. (1975). A re-evaluation of the effect of cysteine on Candida albicans. Sabouraudia 13, 74-82.

Williamson, D. H. \& Scopes, A. W. (1962). A rapid method for synchronizing division in the yeast Saccharomyces cerevisiae. Nature, London 193, 256-257.

WinNer, H. I. \& HuRLEY, R. (1964). Candida albicans, p. 33. London: Churchill. 